\title{
J. G. EMANUEL
}

Joseph George Emanuel, an original member of the Cardiac Club, died in the Queen Elizabeth Hospital on March 3, 1958, at the age of 86 . He was born on June 4, 1871, the eldest son of the Rev. G. J. Emanuel, Minister of the Birmingham Hebrew Congregation. He was educated at King Edward's School, Birmingham, and at Mason's and Queen's Colleges, the predecessors of Birmingham University and its Faculty of Medicine. He graduated B.Sc. London, in 1891 and after qualifying in 1896 held resident posts in several London hospitals. He sailed to Australia and back in 1897-98, as medical officer in a sailing ship, an experience that was unusual even in those days and one that made a deep and lasting impression on him. He was fond of recounting how he gained a reputation - not for treating a sailor seriously injured in a storm, with no assistance and very inadequate equipment, while almost prostrate with sea sickness; but for the anxious care with which he looked after the cook to whom he had inadvertently given an overdose of calomel.

After his return to England, he became R.M.O. at the City of London Hospital for Diseases of the Chest for eighteen months until, in 1900, he finally returned to Birmingham, first as Resident Pathologist at the General Hospital. He obtained the M.R.C.P. in 1902 and the M.B., B.Ch. of the recently founded Birmingham University in the same year.

He became Physician to Out-Patients of the Queen's Hospital, Birmingham, in 1902 and Physician in 1909, and was appointed to the Children's Hospital in 1904. During the 1914-18 war, he was a captain in the R.A.M.C. and served in France with the 56th General Hospital, after which he returned to his hospital and consulting practice. He was elected F.R.C.P. in 1921.

His medical interests were wide, and his early publications were concerned with a wide variety of subjects, and even to the end he regarded himself as a general physician with a special interest in heart disease. He was fortunate in spending his professional life during a period when, the foundations of morbid anatomy having been laid, a tremendous burst of new techniques, new ideas, and new discoveries began to transform the art of medicine into a science, a process of which Emanuel approved, though with some reservations. He witnessed the birth of radiology and serology, and introduced into Birmingham the use of the Widal reaction and of dyes for the differential staining of blood cells. Later he took up with enormous zest the new techniques introduced by Mackenzie and Lewis, and was for many years the only physician in the Midlands who understood the mysteries of the polygraph and electrocardiograph. Most of his later papers were concerned with the cardiac arrhythmias.

He gave the Ingleby Lectures at Birmingham University on auricular fibrillation in 1925 . In addition to a useful review of what was known about it, he analysed the activity of the patient at the moment this rhythm started and concluded that as a rule its onset was not influenced by what the patient was doing at the time.

The retiring age for physicians at the Hospital was then 60, and he reached this age in June 1931, while still at the height of his powers. He continued, however, as Joint Professor of Medicine-a post to which he had been elected in 1930-for another three years, and with a busy consulting practice for several years after, so that he had practiced in Birmingham as a consulting physician for more than half a century. He remained deeply interested in the affairs of the Birmingham Teaching Hospitals, and served on their committees for many years. He kept his interest in new ideas after his retirement, and watched with interest, though perhaps with slight disapproval, the development of physiological methods in cardiological investigation. He regularly attended the meetings of the Cardiac Society until he was nearly 80, and occasionally after that. The esteem and 
affection in which he was held by his colleagues was shown by his election to the Presidency of the Association of Physicians in 1939.

It is not for great discoveries that Emanuel will be remembered: the great influence he exerted was due to the force of his teaching and the sweetness and essential goodness of his character. $\mathrm{He}$ always listened patiently to what his colleagues and students had to say, and would consider it from every imaginable point of view (some that, we thought, nobody but Emanuel could imagine!), and this sometimes made him appear slow and hesitant. If the idea appeared valid, he would warmly and generously accept it, even if contrary to his previous views; but if not, a simple and seemingly innocent question would expose any superficiality of thought, though he asked this gently and without derision. He was a model of kindness, politeness, and consideration for his patients. $\mathrm{He}$ exacted the highest standards from his subordinates and would not tolerate shoddy work: to work for him was not easy, but a great experience. Very many of his house physicians remained his friends for life.

In his personal relations he was the essence of friendliness, kindness, and open-handed but unobtrusive generosity. Many people came to him for advice and help, and none went empty away. No trouble was too great for him to take on behalf of those who needed his help. He was diffident and humble, with no trace of assertiveness in his make-up. If his rise had depended on trampling on others weaker than himself, he would never have risen.

In spite of his contemplative temperament, he had great physical energy. He and his gracious wife, whose sudden death in 1951 was so crushing a blow to him, were members of the Midland Association of Mountaineers, and did a great deal of climbing in North Wales, the Alps, and the Pyrennees. Even in his eighties he scorned to travel any distance less than three miles except by brisk walking. The amputation of a foot in 1956 finally deprived him of this pleasure, but he still remained interested in his garden, his hot-house carnations, and his wide circle of friends. To the end he retained his clearness of mind and his kindness and consideration for others. He died honoured and mourned by all who knew him.

He married Ethel, a daughter of Dr. Alfred Wolff. Their only child, Richard Emanuel, is a member of the British Cardiac Society.

O. BRENNER 